The consequence of all this is that, when the patient's health is sufficiently re-established, permission has been given to join the rest of the family; and I am satisfied that the patient might also be speedily restored to society with perfect safety. In no instance have I known any harm to arise from this permission. During the convalescence of the patient the bath, of course, may be used daily, or every other day, according to the feelings or wish of the patient; but its temperature should be gradually reduced, so as to invig rate and not exhaust, and also to enable the surface sucvesstully to resist the alternations of heat and cold to whic 1 tae patient may be exposed in moving about from place to place.

The terrible sequelæ of this formidable disease are, also, by the treatment above recommended, seldom if ever met wita. No nurse or washerwoman has, to my knowledge, suffered from the performance of her avocations. Of course the necessary medicines must be administered as occasion requires.

St. George's-road, Pimlico, Feb. 1869.

\section{CARBOLIC ACID IN THE TREATMENT OF CERTAIN DISEASES OF THE SKIN.}

\section{BY W. ST. JOHN COLEMAN, L.R.C.P., L.R.C.S.I.,} MEDTCAL OFFICER OF THE MILTOWN MATBAY DISPENSARY DISTRICT.

IT is in the treatment of the numerous class of skin diseases, more than any other, that the practitioner meets with the most provoking disappointments. It will be therefore not out of place to state briefly here the history of some cases treated with a new remedy, and the success which attended its application.

Eariy in October of last year I was consulted by Miss for a troublesome affection of the ears and forefinger of the left hand, which I made out to be eczema chronicum. I treated this with an ointment of white wax, hydrocyanic acid, and glycerine, and the exhibition of lime-water, and subsequently of iodide of potassium, internally. Having had, sume short time previously, some wounds under my care which I treated with a lotion of carbolic acid with much satisfaction, I bethought me that the same protection which this agent affords to nature in the suppurative proces in cases of wounds might equally be availed of in the heal ing pr scess attempted in the altered cutis. To an eightounce phial of glycerine and water $I$ added about twenty miaims* of pure carbolic acid, and applied it to the ears and finger sight and morning. The application exceeded $m y$ expectitions, and the eruption disappeared in a week, leaving a perfectly natural surface beneath. This lady had also her right leg affected with eczema xubrum, which had become c.rronic some three months previous to my treating her. 'lo this also the lotion was applied, and with perfect success.

Mrs D- had been treated by several physicians, myse'f mong the number, for the most troublesome and obstinate uruption of eczema faciei I have seen. From the success which attended the application of carbolic acid in Miss - 's case, I determined to try it in this. I did so, and with this result: that, whilst using the lotion, the face is perfectly smooth, and free from any trace of eruption; but, on its discontinuance, it invariably returns, though in a mitigated degree.

I do not know how many attempts I made to cure $D$. Cface was completely masked, several parts of his body being also affected. I only know that I was unsuccessful, and that othors were equally so. With the history of the cases related above before me, I could not do otherwise than give the carbolic acid a trial. Every bit of the scaly mask is now cleared off, and the skin, although presenting the characteristic redness, does so daily less in intensity, and is just recovering its natural softness.

I will add, as of much importance to the veterinary profession, that I have used a stronger lotion with much success in the treatment of "scab" in sheep.

Miltown Malbay, Co. Clare, Jan. 1869

\section{CASE OF TETANUS CURED BY BROMIDE OF POTASSIUM.}

\author{
BY R. H. BAKEWELL, M.D., M.R.C.S. ENa.
}

ON the 2nd January, 1869, I was called in to see a negress, aged about forty, living in a country village in Trinidad. I found her suffering from great pain, swelling, and tenderness of the left leg, on which there were two or three small but sloughy-looking ulcers. She was in a state of high fever. There was a very strong smell of garlic in the room, and I found that a good woman of the place had been rubbing the leg, including the sores, with a compound of garlic and oil.

I found, on inquiry, that the patient was a washerwoman, pursuing her avocation in the river, and that she had "caught cold" in the leg, which had inflamed and ulcerated. The reason why I was called was that on the previous day she had been attacked with stiffness in the jaws and inability to open them more than half an inch, and that on the morning of my visit she had had a violent spasm of the masseters, during which the jaws were completely clenched, with great pain. She complained, on inquiry, of pain in the back.

I ordered the immediate application of warm poultices and emollient fomentations to the leg; that beef-tea should be given every three hours, and half a drachm of bromide of potassium immediately, to be followed by a similar dose every four hours.

On my visit in the evening I found her in every respect better: the trismus had entirely disappeared, and she could open her mouth to its fullest extent; the pain in the back had gone, and the leg was less inflamed. As her head was somewhat giddy, and she had taken a drachm of the bromide, I ordered it to be discontinued; the other parts of the treatment as before.

She continued daily to improve; there was never any return of the lock-jaw; and she is now (Jan. 23rd) quite well.

Remarks.-This case is not of much importance by itself, but it may suggest to other practitioners the use of the bromide in tetanus, if it has not already been so used. I find nothing about its employment in this disease in the biennial report of the New Sydenham Society, nor have I noticed it in any of the medical journals.

Port of Spain, Trinidad, W.I.

\section{A ithinror}

OF THE PRACTICE OF

\section{MEDICINE AND SURGERY} IN THE

\section{HOSPITALS OF LONDON.}

Nulla autem est alia pro certo noscendi via, nisi quamplurimas et morborum et dissectionum historias, tum aliorum, tum proprias collectas habere, et et dissectionum historias, tum alorum, tum proprias collectas habere, et
inter se comparare.-Morgagn De Sed. et Caus. Morb., lib. iv. Procemium.

\section{KING'S COLLEGE HOSPITAL.}

CASE OF ASCITES DEPENDENT ON CIRRHOSIS OF THE LIVER, TREATED BY COPAIBA.

(Under the care of Dr. DUFFIN.)

A shorr time since, Dr. Garrod called our attention, whilst going round with him, to several of his dropsical patients who were taking copaiba with the effect of largely increasing the quantity of urine passed. In the following case Dr. Duffin employed the same remedy, with results which are very gratifying.

J. W-, aged fifty-one. During his younger years he had been a marine. He had resided both in the East and West Indies and on the shores of the Black Sea, and had suffered from dysentery and jungle fever. He admitted 